\title{
Effect of Seed Rate and Nutrition on Water Use Efficiency and Yield of Hydroponics Maize Fodder
}

\author{
${ }^{1}$ Department of Agronomy, College of Agriculture, ${ }^{2}$ Agronomist, AICRP for Dry land \\ Agriculture, ${ }^{3} Z A R S,{ }^{4}$ Department of SS\&AC, UAS, GKVK, Bangalore - 560 065, India \\ ${ }^{5}$ Department of Microbiology, CoA, VC Farm, Mandya, India
}

*Corresponding author

\section{Keywords}

Fodder maize,

Fodder yield,

Hydroponics,

Nutrition, Seed rate and water use efficiency

\section{Article Info}

Accepted:

15 December 2019

Available Online:

20 January 2020
Experiment on "Effect of seed rate and nutrition on water use efficiency and yield of hydroponics maize fodder" was carried out at AICRP on Dry Land Agriculture, University of Agricultural Science, GKVK, Bengaluru during 2017-18. The experiment was laid with Completely Randomized Design having five repetitions with six seed rate treatments viz., 1.50, 1.75, 2.00, 2.25, 2.50 and $2.75 \mathrm{~kg} \mathrm{~m}^{-2}$. Seed rate with $2.75 \mathrm{~kg} \mathrm{~m}^{-2}$ recorded significantly higher water use efficiency $(612.22 \mathrm{~kg}$ $\left.\mathrm{m}^{-3}\right)$ as compared to $1.50 \mathrm{~kg} \mathrm{~m}^{-2}\left(379.01 \mathrm{~kg} \mathrm{~m}^{-3}\right)$ and it was on par with $2.50 \mathrm{~kg} \mathrm{~m}^{-}$ ${ }^{2}\left(599.63 \mathrm{~kg} \mathrm{~m}^{-3}\right)$. Nutritional experiment was laid in Completely Randomized Design with factorial concept with three repetitions each using four different nutrient sources(urea @ $1 \%$, MOP @ $1 \%$, urea and MOP each @ $1 \%$ and 19:19:19@1\%) and two levels of spray schedules (one spray at 6 DAS and two sprays at 3 and 10 DAS) and no spray was taken as control. In nutrient study 2.50 $\mathrm{kg} \mathrm{m}^{-2}$ was taken as standard seed rate and Significantly higher water use efficiency was recorded with two sprays of urea and MOP each @ 1 per cent at 3 and 10 DAS $\left(744.46 \mathrm{~kg} \mathrm{~m}^{-3}\right)$ as compared to control $\left(598.96 \mathrm{~kg} \mathrm{~m}^{-3}\right)$.

\section{Introduction}

Water and agriculture are highly interdependent and critical to the well-being, economy, and security of most societies. In India, livestock plays an important role for nutritional and livelihood security of small and marginal farmers. The increased livestock population demands higher fodder in the country. The scarcity of fodder and land allocation for cultivation of green fodder lead to reduced productivity of livestock. Also, 
fodder production is constrained further with climate change impacted through erratic distribution of rainfall.

These problems can be cope alternatively by producing green fodder for farm animals through hydroponics technology (Sneath and McIntosh, 2003; Naik et al., 2015). Hydroponics is an art and technology that has revolutionizing the green fodder production during $21^{\text {st }}$ century. This is a concept of growing crops without soil in the presence of water and proper nutrition. This process takes place in a very versatile and intensive growing unit where only water and nutrients are used to produce a grass and root combination which is very lush green and rich in nutrients.

Maize is an important cereal having diversified usage. Apart from grain consumption, it is also used as fodder due to its higher fresh biomass. Maize is a better choice for production of hydroponic fodder due to its availability, lower cost of seeds, higher biomass production, higher seed to biomass ratio and quicker growing habit (Naiket al., 2012).Hydroponic fodder production is a recent technology in India and demands standardization of agro-techniques scientifically. Optimum seed rate is the primary aspect in the agro-techniques, as the productivity, profitability and quality are associated with it. Hence, experiments on "Effect of seed rate and nutrition on water use efficiency and yield of hydroponics maize fodder" was conducted at AICRP for Dry Land Agriculture, UAS, GKVK, Bengaluru during 2017-18.

\section{Materials and Methods}

The research was conducted in the hydroponic facility of AICRP for Dry Land Agriculture, UAS, GKVK, Bengaluru in two batches to study the "Effect of seed rate and nutrition on Water use efficiency and yield of hydroponics maize fodder". Experiment was laid out in Completely Randomized Design with five repetitions having six seed rate treatments viz., $1.50,1.75,2.00,2.25,2.50$ and $2.75 \mathrm{~kg} \mathrm{~m}^{-2}$. Nutritional experiment was laid in Completely Randomized Design with factorial concept with three repetitions each using four different nutrient sources(urea @ 1\%, MOP @ 1\%, urea and MOP each @ 1\% and 19:19:19 @ 1 $\%)$ and two levels of spray schedules (one spray at 6 DAS and two sprays at 3 and 10 DAS) and no spray was taken as control. Soaking of seeds for 24 hours will enhance the rapid uptake of water for facilitating the metabolism and utilization of reserved food of the seeds for growth and development. Then water was drained and the seeds placed in wet gunny bags and kept for initiating germination process. The experiment was conducted using vinyl fibre trays of dimensions $2.5 \times 1.5 \times 0.15$ $\mathrm{ft}$. The daily total water added and drained water out of trays throughout the course of experiment were recorded per tray to compute for total water use and water use efficiency. The total water used by plants (liters/tray) is calculated using following equation (Al-Ajmi et al., 2009)

Total water use $=$ Total added water in irrigation - Total drained water out of trays.

Water use efficiency (WUE) in $\mathrm{kg}$ fresh weight $\mathrm{m}^{-3}$ water was computed according to the equation:

$$
\begin{aligned}
& \text { WUE }\left(\mathrm{kg} \mathrm{m}^{-3}\right) \\
& \text { Total green fodder } \\
& \text { produced }(\mathrm{kg}) \\
& =\text {-.--.-- } 1000
\end{aligned}
$$

Total water used (liter)

The green fodder is harvested after 14 DAS and the weight of each tray containing green fodder is recorded and expressed in $\mathrm{kg} \mathrm{m}^{-}$ ${ }^{2}$.The experimental data was analysed using Fisher's method of "Analysis of Variance" 
(ANOVA) as given by Gomez and Gomez (1984). All the data obtained were analyzed and the results are presented and discussed at a probability level of 0.01 per cent. In nutrition experiment the analysis of variance (ANOVA) is worked out with 2 way analysis to elicit the individual effect of nutrient source and spray schedule considering $8 \quad(4 \times 2)$ treatments besides 9 treatments combinations (including control) with one way ANOVA for comparison.

\section{Results and Discussion}

Yield and yield per kg seed of fodder maize as influenced by seed rate under hydroponics

Yield is the resultant of different metabolic activities taking place in different stages of the growth of the plants. Fodder yield of the crop depends on both external and internal factors. Internal factors like growth and yield parameters viz., dry matter accumulation and distribution in different growth stages, fresh weight and dry weight of the individual plants at harvest, seedling vigour, shoot length and root length and external factors like optimum light, water and nutrients.

The green fodder yield of hydroponically grown fodder maize influenced significantly by different seed rates (Table 1). Seed rate of $2.75 \mathrm{~kg} \mathrm{~m}^{-2}$ recorded significantly higher green fodder yield $\left(11.81 \mathrm{~kg} \mathrm{~m}^{-2}\right.$ as compared to $1.50 \mathrm{~kg}$

$\mathrm{m}^{-2}\left(6.01 \mathrm{~kg} \mathrm{~m}^{-2}\right)$. However, it was on par with $\left.2.50 \mathrm{~kg} \mathrm{~m}^{-2}\left(11.49 \mathrm{~kg} \mathrm{~m}^{-2}\right)\right)$. Seed rate with $2.50 \mathrm{~kg} \mathrm{~m}^{-2}$ has recorded 47.69 per cent higher fodder yield than seed rate with $1.50 \mathrm{~kg} \mathrm{~m}^{-2}$.

Similar trends were also observed during both the batches. Increased seed rate increased the green fodder yield significantly due to increased number of plant population. The higher green fodder yield is attributed by higher yield parameters like fresh weight of shoot, root and seed and total dry matter accumulation in shoot, root and seed. ElMorsyet al., (2013) and Naik et al., (2017) also reported an increased fresh green yield of barley and maize with increased seed rate.

The green fodder yield per $\mathrm{kg}$ of seeds was significantly higher at a seed rate of $2.5 \mathrm{~kg} \mathrm{~m}^{-2}$ (4.60 $\mathrm{kg} \mathrm{kg}^{-1}$ seed) as compared to $1.50 \mathrm{~kg} \mathrm{~m}^{-2}$ (4.00 kg kg-1 seed). However, it was at par with $2.25 \mathrm{~kg} \mathrm{~m}^{-2}$ (4.42 kg kg${ }^{-1}$ seed), $2.75 \mathrm{~kg} \mathrm{~m}^{-}$ ${ }^{2}\left(4.30 \mathrm{~kg} \mathrm{~kg}^{-1}\right.$ seed) and $2.00 \mathrm{~kg} \mathrm{~m}^{-2}(4.20 \mathrm{~kg}$ $\mathrm{kg}^{-1}$ seed) (Table 1). Seed rate with $2.5 \mathrm{~kg} \mathrm{~m}^{-2}$ has recorded 13.04 per cent higher green fodder yield per $\mathrm{kg}$ seeds than seed rate of $1.50 \mathrm{~kg} \mathrm{~m}^{-2}$. The higher green fodder yield per $\mathrm{kg}$ seeds might be attributed by higher yield parameters viz., fresh weight of shoot, root and seed per $\mathrm{kg}$ seeds and total dry matter accumulation in shoot, root and seed per $\mathrm{kg}$ seeds. These yield parameters depend upon growth parameters like shoot length, root length and seedling vigour, which contributed to increase in fodder yield.

The green fodder yield of the maize per $\mathrm{kg}$ seed sown was increased up to $2.5 \mathrm{~kg} \mathrm{~m}^{-2}$ thereafter it decreased, may be due to increased seed density might have increases the intra plant competition for space, light and water, resulted in decreased individual plant fresh weight of shoot and root, individual plant dry weight of shoot, root, shoot length and root length. The increased seed density might further increased temperature of the microclimate owing to higher plant respiration and leading to lower accumulation of dry matter. Moreover increased seed rate will lead to more microbial growth in root mat which effect the growth of individual plants. Naik et al., (2017) also reported the fresh yield of the maize grown hydroponically will increase with increase in seed rate up to some extent thereafter it will reduce drastically.

Water use efficiency fodder maize as 


\section{influenced by seed rate under hydroponics}

Water is one of the basic requirements for seed germination and seedling growth as it is essential for enzyme activation, reserve storage, breakdown, translocation, and use in seed germination and seedling growth (Copeland and Macdonald, 1995).

Seed rate with $2.75 \mathrm{~kg} \quad \mathrm{~m}^{-2}$ recorded significantly higher water use efficiency $\left(612.22 \mathrm{~kg} \mathrm{~m}^{-3}\right)$ as compared to $1.50 \mathrm{~kg} \mathrm{~m}^{-2}$ $\left(379.01 \mathrm{~kg} \mathrm{~m}^{-3}\right)$ and it was on par with $2.50 \mathrm{~kg}$ $\mathrm{m}^{-2}\left(599.63 \mathrm{~kg} \mathrm{~m}^{-3}\right)$ (Table 2). The higher water use efficiency under seed rate of $2.50 \mathrm{~kg}$ $\mathrm{m}^{-2}$ is mainly associated with higher fodder yield per unit area with same rate of water application (Table 1).This is a tremendous improvement in WUE and indicated that hydroponic system could play a significant role in saving water to produce green fodder in high amounts. This was in conformity with Al-Ajmiet al., (2009), Al-Karaki and AlHashimi (2012).

From the above results, the $2.5 \mathrm{~kg} \mathrm{~m}^{-2}$ showed higher fodder production and WUE under hydroponic conditions.

Yield and yield per kg seed of fodder maize as influenced by foliar nutrition under hydroponics

The yield of the crop largely depend on interactions of various physiological, biochemical and morphological changes takes place during growth and development of crops and it also depends on optimum availability of resources like nutrients, space, light and water. The nutrients plays an important role in physiological and biochemical processes in plant influencing growth, development and finally the yield. Fodder yield of the hydroponically grown fodder maize differ significantly among different foliar nutrition and time of spray (Table 3).

Combined application of urea and MOP each@1 per cent recorded significantly higher fodder maize yield $\left(13.25 \mathrm{~kg} \mathrm{~m}^{-2}\right)$ as compared to individual spray viz., MOP @ 1 per cent spray $\left(11.87 \mathrm{~kg} \mathrm{~m}^{-2}\right), 19: 19: 19$ @ 1 per cent spray $\left(12.27 \mathrm{~kg} \mathrm{~m}^{-2}\right)$ and urea @ 1 per cents pray(12.24 $\left.\mathrm{kg} \quad \mathrm{m}^{-2}\right)$. Combined foliar application of urea and MOP each at 1 per cent has recorded 10.41, 7.62 and 7.39 per cent higher fodder yield compared individual spray of MOP at 1 per cent, 19:19:19 at 1 per cent and urea at 1 per cent, respectively.

Increased fodder yield of maize is associated with combined spray of urea and MOP each at 1 per cent is mainly due to combined application of nitrogen and potassium has cumulative effect on growth and development of fodder maize, because nitrogen plays a dominant role in the meristematic activity and cell division which in turn increased number of cells leading to improved vegetative growth and dry matter accumulation, whereas potassium activates enzymes which are involved in protein synthesis and carbohydrate translocation which might helped for vigorous root development, growth and development of plant leading to increased fodder yield.

MutumLamnganbi and Surve (2017) also stated that application of foliar nutrients increased fodder yield of white and yellow maize significantly compared to control.

Foliar spray of nutrients at different growth stages influenced fodder yield of hydroponically grown fodder maize significantly. 
Table.1 Yield and yield per kg seed of fodder maize as influenced by seed rate under hydroponics

\begin{tabular}{|c|c|c|c|c|c|c|}
\hline \multirow[t]{2}{*}{ Treatment - Seed rate } & \multicolumn{3}{|c|}{ Yield $\left(\mathrm{kg} \mathrm{m}^{-2}\right)$} & \multicolumn{3}{|c|}{ Yield per kg seeds (kg) } \\
\hline & Batch 1 & Batch 2 & Pooled & Batch 1 & Batch 2 & Pooled \\
\hline$T_{1}: 1.50 \mathrm{~kg} \mathrm{~m}^{-2}$ & 5.93 & 6.08 & 6.01 & 3.95 & 4.05 & 4.00 \\
\hline$T_{2}: 1.75 \mathrm{~kg} \mathrm{~m}^{-2}$ & 6.43 & 7.67 & 7.05 & 3.68 & 4.38 & 4.03 \\
\hline$T_{3}: 2.00 \mathrm{~kg} \mathrm{~m}^{-2}$ & 7.83 & 8.97 & 8.40 & 3.92 & 4.48 & 4.20 \\
\hline $\mathrm{T}_{4}: 2.25 \mathrm{~kg} \mathrm{~m}^{-2}$ & 8.95 & 10.92 & 9.94 & 3.98 & 4.85 & 4.42 \\
\hline$T_{5}: 2.50 \mathrm{~kg} \mathrm{~m}^{-2}$ & 11.06 & 11.93 & 11.49 & 4.42 & 4.77 & 4.60 \\
\hline $\mathrm{T}_{6}: 2.75 \mathrm{~kg} \mathrm{~m}^{-2}$ & 11.58 & 12.04 & 11.81 & 4.21 & 4.38 & 4.30 \\
\hline S. Em. \pm & 0.23 & 0.23 & 0.23 & 0.11 & 0.12 & 0.12 \\
\hline CD @ $1 \%$ & 0.92 & 0.91 & 0.88 & 0.43 & 0.48 & 0.44 \\
\hline
\end{tabular}

Table.2 Water use efficiency of fodder maize as influenced by seed rate under hydroponics

\begin{tabular}{|c|c|c|c|c|c|c|c|c|c|}
\hline \multirow[t]{2}{*}{ Treatment - Seed rate } & \multicolumn{3}{|c|}{ Yield $\left(\mathrm{kg} \mathrm{m}^{-2}\right)$} & \multicolumn{3}{|c|}{$\begin{array}{l}\text { Total water use } \\
\quad\left(\text { litres } \mathbf{~ m}^{-2}\right)\end{array}$} & \multicolumn{3}{|c|}{ WUE $\left(\mathrm{kg} \mathrm{m}^{-3}\right)$} \\
\hline & Batch 1 & Batch 2 & Pooled & Batch 1 & Batch 2 & Pooled & Batch 1 & Batch 2 & Pooled \\
\hline$T_{1}: 1.50 \mathrm{~kg} \mathrm{~m}^{-2}$ & 5.93 & 6.08 & 6.01 & 16.20 & 15.52 & 15.86 & 366.14 & 391.88 & 379.01 \\
\hline$T_{2}: 1.75 \mathrm{~kg} \mathrm{~m}^{-2}$ & 6.43 & 7.67 & 7.05 & 16.56 & 16.46 & 16.51 & 388.30 & 465.97 & 427.13 \\
\hline$T_{3}: 2.00 \mathrm{~kg} \mathrm{~m}^{-2}$ & 7.83 & 8.97 & 8.40 & 17.23 & 16.95 & 17.08 & 454.40 & 529.13 & 491.76 \\
\hline$T_{4}: 2.25 \mathrm{~kg} \mathrm{~m}^{-2}$ & 8.95 & 10.92 & 9.94 & 18.74 & 18.53 & 18.63 & 477.57 & 589.25 & 533.41 \\
\hline$T_{5}: 2.50 \mathrm{~kg} \mathrm{~m}^{-2}$ & 11.06 & 11.93 & 11.49 & 19.24 & 19.10 & 19.16 & 574.81 & 624.45 & 599.63 \\
\hline$T_{6}: 2.75 \mathrm{~kg} \mathrm{~m}^{-2}$ & 11.58 & 12.04 & 11.81 & 19.69 & 18.92 & 19.29 & 587.97 & 636.47 & 612.22 \\
\hline S.Em. \pm & 0.23 & 0.23 & 0.23 & - & - & - & 7.25 & 6.30 & 6.79 \\
\hline CD@ $1 \%$ & 0.92 & 0.91 & 0.88 & - & - & - & 28.69 & 24.90 & 25.76 \\
\hline
\end{tabular}


Table.3 Yield and yield per kg seed of fodder maize as influenced by foliar nutrition under hydroponics

\begin{tabular}{|c|c|c|c|c|c|c|}
\hline \multirow[t]{2}{*}{ Treatments } & \multicolumn{3}{|c|}{ Yield $\left(\mathrm{kg} \mathrm{m}^{-2}\right)$} & \multicolumn{3}{|c|}{ Yield per kg seed (kg) } \\
\hline & Batch 1 & Batch 2 & Pooled & Batch 1 & Batch 2 & Pooled \\
\hline \multicolumn{7}{|c|}{ A: Nutrient source } \\
\hline$A_{1}:$ Urea@1\% & 12.08 & 12.4 & 12.24 & 4.83 & 4.96 & 4.9 \\
\hline A $:$ MOP @ $1 \%$ & 11.83 & 11.9 & 11.87 & 4.73 & 4.76 & 4.75 \\
\hline A3: Urea @1\% and MOP @ $1 \%$ & 13.19 & 13.31 & 13.25 & 5.28 & 5.33 & 5.3 \\
\hline A4: 19:19:19@1 \% & 12.26 & 12.28 & 12.27 & 4.9 & 4.91 & 4.91 \\
\hline S. Em. \pm & 0.16 & 0.14 & 0.11 & 0.06 & 0.06 & 0.04 \\
\hline CD@1\% & 0.66 & 0.57 & 0.41 & 0.26 & 0.23 & 0.16 \\
\hline \multicolumn{7}{|c|}{ B: Spray schedule } \\
\hline $\mathrm{B}_{1}$ : One spray at 6 DAS & 12.01 & 12 & 12 & 4.8 & 4.8 & 4.8 \\
\hline$B_{2}:$ Two spray at $3 \& 10$ DAS & 12.67 & 12.95 & 12.81 & 5.07 & 5.18 & 5.12 \\
\hline S. Em. \pm & 0.11 & 0.1 & 0.07 & 0.05 & 0.04 & 0.03 \\
\hline CD@1\% & 0.47 & 0.4 & 0.29 & 0.19 & 0.16 & 0.12 \\
\hline \multicolumn{7}{|c|}{ Interaction $(\mathbf{A} \times \mathbf{B})$} \\
\hline $\mathbf{A}_{1} \mathbf{B}_{1}$ & 11.7 & 11.57 & 11.64 & 4.68 & 4.63 & 4.65 \\
\hline $\mathbf{A}_{1} \mathbf{B}_{2}$ & 12.47 & 13.23 & 12.85 & 4.99 & 5.29 & 5.14 \\
\hline $\mathbf{A}_{2} \mathbf{B}_{1}$ & 11.6 & 11.67 & 11.63 & 4.64 & 4.67 & 4.65 \\
\hline $\mathbf{A}_{2} \mathbf{B}_{2}$ & 12.07 & 12.13 & 12.1 & 4.83 & 4.85 & 4.84 \\
\hline $\mathbf{A}_{3} \mathbf{B}_{1}$ & 12.6 & 12.54 & 12.57 & 5.04 & 5.02 & 5.03 \\
\hline $\mathbf{A}_{3} \mathbf{B}_{2}$ & 13.78 & 14.09 & 13.93 & 5.51 & 5.64 & 5.57 \\
\hline $\mathbf{A}_{4} \mathbf{B}_{1}$ & 12.14 & 12.22 & 12.18 & 4.85 & 4.89 & 4.87 \\
\hline $\mathbf{A}_{4} \mathbf{B}_{2}$ & 12.38 & 12.35 & 12.36 & 4.95 & 4.94 & 4.95 \\
\hline S. Em. \pm & 0.23 & 0.2 & 0.15 & 0.09 & 0.08 & 0.06 \\
\hline CD@ 1\% & NS & 0.81 & 0.58 & NS & 0.32 & 0.23 \\
\hline Control & 11.57 & 11.48 & 11.53 & 4.63 & 4.59 & 4.61 \\
\hline S. Em. \pm & 0.22 & 0.2 & 0.15 & 0.09 & 0.08 & 0.06 \\
\hline CD@1\% & 0.91 & 0.82 & 0.59 & 0.36 & 0.33 & 0.23 \\
\hline
\end{tabular}


Table.4 Water use efficiency of fodder maize as influenced by foliar nutrition under hydroponics

\begin{tabular}{|c|c|c|c|c|c|c|c|c|c|}
\hline \multirow[t]{2}{*}{ Treatments } & \multicolumn{3}{|c|}{ Yield $\left(\mathrm{kg} \mathrm{m}^{-2}\right)$} & \multicolumn{3}{|c|}{ Total water use } & \multicolumn{3}{|c|}{ WUE $\left(\mathrm{kg} \mathrm{m}^{-3}\right)$} \\
\hline & Batch 1 & Batch 2 & Pooled & Batch 1 & Batch 2 & Pooled & Batch 1 & Batch 2 & Pooled \\
\hline \multicolumn{10}{|c|}{ A: Nutrient source } \\
\hline$A_{1}:$ Urea@1\% & 12.08 & 12.4 & 12.24 & 18.80 & 18.72 & 18.76 & 642.61 & 662.39 & 652.48 \\
\hline A2:MOP@1\% & 11.83 & 11.9 & 11.87 & 18.76 & 18.77 & 18.76 & 630.71 & 634.16 & 632.70 \\
\hline A3:Urea@1\% and MOP @ 1 & 13.19 & 13.31 & 13.25 & 18.71 & 18.74 & 18.72 & 705.16 & 710.12 & 707.64 \\
\hline$A_{4}: 19: 19: 19 @ 1 \%$ & 12.26 & 12.28 & 12.27 & 18.76 & 18.58 & 18.67 & 653.69 & 660.93 & 657.29 \\
\hline S. Em. \pm & 0.16 & 0.14 & 0.11 & - & - & - & 8.53 & 7.41 & 5.65 \\
\hline CD@1\% & 0.66 & 0.57 & 0.41 & - & - & - & 35.22 & 30.59 & 21.87 \\
\hline \multicolumn{10}{|c|}{ B: Spray schedule } \\
\hline $\mathrm{B}_{1}$ : One spray at 6 DAS & 12.01 & 12 & 12 & 18.77 & 18.67 & 18.73 & 639.54 & 642.43 & 640.71 \\
\hline$B_{2}:$ Two spray at $3 \& 10$ DAS & 12.67 & 12.95 & 12.81 & 18.72 & 18.72 & 18.72 & 676.52 & 691.59 & 684.05 \\
\hline S. Em. \pm & 0.11 & 0.1 & 0.07 & - & - & - & 6.03 & 5.24 & 3.99 \\
\hline CD@1\% & 0.47 & 0.4 & 0.29 & - & - & - & 24.91 & 21.63 & 15.46 \\
\hline \multicolumn{10}{|c|}{ Interaction $(\mathbf{A} \times \mathbf{B})$} \\
\hline $\mathbf{A}_{1} \mathbf{B}_{1}$ & 11.7 & 11.57 & 11.64 & 18.78 & 18.72 & 18.75 & 623.00 & 618.06 & 620.80 \\
\hline $\mathbf{A}_{1} \mathbf{B}_{2}$ & 12.47 & 13.23 & 12.85 & 18.82 & 18.72 & 18.77 & 662.71 & 706.73 & 684.66 \\
\hline $\mathbf{A}_{2} \mathbf{B}_{1}$ & 11.6 & 11.67 & 11.63 & 18.90 & 18.65 & 18.78 & 613.76 & 625.74 & 619.44 \\
\hline $\mathbf{A}_{2} \mathbf{B}_{2}$ & 12.07 & 12.13 & 12.1 & 18.61 & 18.88 & 18.75 & 648.46 & 642.48 & 645.45 \\
\hline $\mathbf{A}_{3} \mathbf{B}_{1}$ & 12.6 & 12.54 & 12.57 & 18.73 & 18.75 & 18.74 & 672.84 & 668.92 & 670.88 \\
\hline $\mathbf{A}_{3} \mathbf{B}_{2}$ & 13.78 & 14.09 & 13.93 & 18.68 & 18.74 & 18.71 & 737.56 & 751.87 & 744.46 \\
\hline$A_{4} B_{1}$ & 12.14 & 12.22 & 12.18 & 18.71 & 18.60 & 18.66 & 648.85 & 656.99 & 652.91 \\
\hline $\mathbf{A}_{4} \mathbf{B}_{2}$ & 12.38 & 12.35 & 12.36 & 18.80 & 18.56 & 18.68 & 658.51 & 665.41 & 661.67 \\
\hline S. Em. \pm & 0.23 & 0.2 & 0.15 & - & - & - & 12.06 & 10.47 & 7.99 \\
\hline CD@1\% & NS & 0.81 & 0.58 & - & - & - & NS & 43.26 & 30.93 \\
\hline Control & 11.57 & 11.48 & 11.53 & 19.2 & 19.3 & 19.25 & 602.60 & 594.82 & 598.96 \\
\hline S. Em. \pm & 0.22 & 0.2 & 0.15 & - & - & - & 11.97 & 10.7 & 8.14 \\
\hline CD@1\% & 0.91 & 0.82 & 0.59 & - & - & - & 48.74 & 43.54 & 31.36 \\
\hline
\end{tabular}


Foliar spray with different nutrients at 3 and 10 DAS recorded significantly higher fodder maize yield $\left(12.81 \mathrm{~kg} \mathrm{~m}^{-2}\right)$ as compared to one spray at 6 DAS $\left(12.00 \mathrm{~kg} \mathrm{~m}^{-2}\right)$. Two spray of foliar nutrients at 3 and 10 DAS recorded 1.06 times higher fodder yield compared to single spray at 6 DAS. The higher yield with two sprays of foliar nutrient at 3 and 10 DAS is mainly due to higher nutrient dose by repeated application. Application of nutrients should be done in such a way that it should synchronize the nutrient supply as per demand. Hence, foliar nutrition twice has increased the fodder yield due to higher yield and growth attributing characters.

The interaction effect of nutrient source and spray schedule influenced the fodder yield of hydroponically grown maize significantly (Table 3). Significantly higher fodder yield of maize was recorded with the two combined sprays of urea and MOP each @ 1 per cent at 3 and 10 DAS $\left(13.93 \mathrm{~kg} \mathrm{~m}^{-2}\right)$ as compared to control (11.53 $\mathrm{kg} \mathrm{m}^{-2}$ ), followed by urea @ 1 per cent at 3 and 10 DAS $\left(12.85 \mathrm{~kg} \mathrm{~m}^{-2}\right)$, urea and MOP each @ 1per cent at 6 DAS (12.54 $\mathrm{kg} \mathrm{m}^{-2}$ ), 19:19:19@1per cent at 3 and 10 DAS (12.36 kg m²), 19:19:19 @ 1per cent at 6 DAS (12.18 kg m$\left.{ }^{-2}\right)$, MOP @ 1per cent at 3 and 10 DAS $\left(12.10 \mathrm{~kg} \mathrm{~m}^{-2}\right)$, urea @ 1per cent at 6 DAS (11.64 $\mathrm{kg} \mathrm{m}^{-2}$ ) and MOP @ 1 per cent at 6 DAS $\left(11.63 \mathrm{~kg} \mathrm{~m}^{-2}\right)$.

Higher fodder yield of maize with combined spray of urea and MOP each @ 1 per cent at 3 and 10 DAS is mainly due to significantly higher fresh weight of shoot, root and seed, higher dry matter accumulation at different growth stage and their partitioning into different parts of the crop viz., shoot and root. The higher dry matter accumulation and their translocation into different parts might be attributed to higher photosynthetic activity which mainly influenced by nitrogen and potassium nutrition and synchronized supply according to the crop demand.
Water use efficiency $\left(\mathrm{kg} \mathrm{m}^{-3}\right)$ of fodder maize as influenced by foliar nutrition under hydroponics

Among different nutrient sources combined foliar application of urea and MOP each @ 1 per centre corded significantly higher water use efficiency $\left(707.64 \mathrm{~kg} \mathrm{~m}^{-3}\right)$ as compared to MOP @ 1per cent $\left(632.70 \mathrm{~kg} \mathrm{~m}^{-3}\right)$, which is followed by urea @ 1per cent $\left(652.48 \mathrm{~kg} \mathrm{~m}^{-3}\right)$ and 19:19:19@1 per cent $\left(657.29 \mathrm{~kg} \mathrm{~m}^{-3}\right)$. Application of urea @1 per cent and MOP @ 1 per cent has recorded 13.03 per cent higher than control (Table 4).

Among different spray schedule, two spray of nutrients at 3 and 10 DAS recorded significantly higher water use efficiency $\left(684.05 \mathrm{~kg} \mathrm{~m}^{-3}\right)$ as compared to one spray at 6 DAS $\left(640.71 \mathrm{~kg} \mathrm{~m}^{-3}\right)$.

The interaction effect of nutrient source and spray schedule recorded significant difference on water use efficiency. Significantly higher water use efficiency was recorded with two sprays of urea and MOP each @ 1 per cent at 3 and 10 DAS $\left(744.46 \mathrm{~kg} \mathrm{~m}^{-3}\right)$ as compared to control $\left(619.44 \mathrm{~kg} \mathrm{~m}^{-3}\right)$. It is followed by urea @ 1 per cent at 3 and 10 DAS $\left(684.66 \mathrm{~kg} \mathrm{~m}^{-3}\right)$, urea and MOP each @ 1per cent at 6 DAS $\left(671.47 \mathrm{~kg} \mathrm{~m}^{-3}\right), 19: 19: 19 @ 1$ per cent at 3 and 10 DAS $\left(660.26 \mathrm{~kg} \mathrm{~m}^{-3}\right), 19: 19: 19 @ 1$ per cent at 6 DAS $\left(650.64 \mathrm{~kg} \mathrm{~m}^{-3}\right), \mathrm{MOP} @ 1$ per centat 3 and 10 DAS $\left(645.45 \mathrm{~kg} \mathrm{~m}^{-3}\right)$, urea @1per cent at 6 DAS $\left(620.80 \mathrm{~kg} \mathrm{~m}^{-3}\right)$ and MOP @ 1 per cent at 6 DAS $\left(619.44 \mathrm{~kg} \mathrm{~m}^{-3}\right)$. The higher water use efficiency is due to higher fodder yield of maize in urea and MOP each @ 1per cent at 3 and 10 DAS $\left(13.93 \mathrm{~kg} \mathrm{~m}^{-}\right.$ $\left.{ }^{3}\right)$.The higher water use efficiency is mainly due to combined application of urea and MOP resulted in increased growth and development of shoot and root that in turn might have lead to higher accumulation of dry matter in seedling throughout the growth period. The increase in dry matter accumulation in 
seedlings has increased fresh fodder yield of the hydroponically grown maize, so the fresh green fodder produced per unit water enhanced the water use efficiency of crop applied with nitrogen and potash. This is in conformity with MutumLamnganbi and Surve (2017).

Seed rate of $2.50 \mathrm{~kg} \mathrm{~m}^{-2}$ with two sprays of urea and MOP each @ 1 per cent at 3 and 10 DAS is optimum for better growth, higher water use efficiency and fodder yield of hydroponically grown fodder maize.

\section{References}

Al-Ajmi, A., Salih, A., Kadhim, I. and Othman, Y., 2009, Yield and water use efficiency of barley fodder produced under hydroponic system in GCC countries using tertiary treated sewage effluents. Journal of Phytology, 1(5): 342-348.

Al-Karaki, G. N. and Al-Hashimi, M., 2012, Green fodder production and water use efficiency of some forage crops under hydroponic condition.International Scholarly Research Network, Pp. 1-5.

Copeland, O. L. and Mcdonald M. B., 1995.Seed science and technology. Third Edn., Chapman and Hall. New York.

El-Morsy A. T., Abul-Soud, M. and Emam, M. S. A., 2013, Localized hydroponic green forage technology as a climate change adaptation under Egyptian conditions. Research Journal of Agriculture and Biological Sciences, 9(6):341-350.

Gomez, K. A. and Gomez, A., 1984, Statistical procedures for agricultural research $2^{\text {nd }}$ Edition, John Willey and Sons, Inc. New York, USA. Pp: 234237.

MutumLamnganbi and Surve, U. S., 2017, Biomass yield and water productivity of different hydroponic fodder crops. Journal PharmacognosyPhytoChemistry,6(5): 1297-1300.

Naik, P. K., Dhuri, R. B., Swain, B. K. and Singh, N. P. 2012. Nutrient changes with the growth of hydroponics fodder maize. Indian Journal of Animal Nutrition,29: 161-163.

Naik, P. K., Swain, B. K. and Singh, N. P., 2015, Review-production and utilization of hydroponics fodder. Indian Journal of Animal Nutrition,32(1): 1-9.

Naik, P. K., Swain, B. K., Chakurkar, E. B. and Singh, N. P., 2017, Effect of seed rate on yield and proximate constituents of different parts of hydroponics maize fodder. Indian Journal of Animal Sciences,87 (1): 109-112.

Sneath, R. and McIntosh, F., 2003, Review of hydroponic fodder production for beef, cattle, Queensland government, Department of Primary Industries, Dalby, Queensland.

\section{How to cite this article:}

Santosh Nagappa Ningoji, M. N. Thimmegowda, B. Boraiah, M. R. Anand, R. Krishna Murthy and Asha, N. N. 2020. Effect of Seed Rate and Nutrition on Water Use Efficiency and Yield of Hydroponics Maize Fodder. Int.J.Curr.Microbiol.App.Sci. 9(01): 71-79.

doi: https://doi.org/10.20546/ijcmas.2020.901.008 